\title{
Application of thermodynamic modelling to natural mantle xenoliths: examples of density variations and pressure- temperature evolution of the lithospheric mantle
}

\author{
L. Ziberna ${ }^{1} \cdot$ S. Klemme ${ }^{2}$
}

Received: 9 September 2015 / Accepted: 4 January 2016 / Published online: 23 January 2016

(C) The Author(s) 2016. This article is published with open access at Springerlink.com

\begin{abstract}
In this paper, we show how the results of phase equilibria calculations in different mantle compositions can be reconciled with the evidence from natural mantle samples. We present data on the response of bulk rock density to pressure $(\mathrm{P})$, temperature $(\mathrm{T})$ and compositional changes in the lithospheric mantle and obtain constraints on the P-T evolution recorded by mantle xenoliths. To do this, we examine the mantle xenolith suite from the Quaternary alkali basalts of Pali-Aike, Patagonia, using phase equilibria calculation in six representative compositions. The calculations were done subsolidus and in volatilefree conditions. Our results show that the density change related to the spinel peridotite to garnet peridotite transition is not sharp and strongly depends on the bulk composition. In a depleted mantle composition, this transition is not reflected in the density profile, while in a fertile mantle it leads to a relative increase in density with respect to more depleted compositions. In mantle sections characterized by hot geothermal gradients $\left(\sim 70 \mathrm{~mW} / \mathrm{m}^{2}\right)$, the spinel-garnet transition may overlap with the lithosphere-asthenosphere boundary. Phase equilibria calculations in peridotitic compositions representative of the Pali-Aike mantle were also used to constrain the origin and evolution of the mantle xenoliths. Our results indicate that the mineral modes and compositions, and the mineral zonation reported for the
\end{abstract}

Communicated by Jochen Hoefs.

$\triangle$ L. Ziberna

luca.ziberna@bristol.ac.uk

1 School of Earth Sciences, University of Bristol, Wills Memorial Building, Queen's Rd, Bristol BS8 1RJ, UK

2 Institut für Mineralogie, Westfälische-Wilhelms-Universität Münster, Corrensstrasse 24, 49189 Münster, Germany low-temperature peridotites (spinel and spinel + garnet harzburgites and lherzolites), are linked to a cooling event in the mantle which occurred long before the eruption of the host basalts. In addition, our phase equilibria calculations show that kelyphitic rims around garnets, as those observed in the high-temperature garnet peridotites from Pali-Aike, can be explained simply by decompression and do not require additional metasomatic fluid or melt.

Keywords Density $\cdot$ P-T conditions · Thermodynamic modelling $\cdot$ Upper mantle $\cdot$ Xenoliths

\section{Introduction}

Combining the petrological and geochemical evidence of mantle xenoliths and peridotitic massifs with phase equilibria experiments and thermodynamic modelling is essential to further our understanding of the nature of the upper mantle. While there is a plethora of experimental information on the melting behaviour of upper mantle rocks (e.g. Green and Falloon 1998; Falloon et al. 2001), there is relatively little experimental information on subsolidus phase relations in complex upper mantle compositions (e.g. Green and Ringwood 1967, 1970; O'Hara et al. 1971; Brey et al. 1990). This is probably due to the fact that experiments in complex compositions are characterized by slow reaction rates, slow crystal growth rates and general sluggishness to equilibrate. Therefore, experiments in complex compositions are especially difficult to conduct and experimental results are often difficult to interpret (e.g. Green and Ringwood 1967; Brey et al. 1999; Girnis and Brey 1999; Girnis et al. 2003; Borghini et al. 2009; Fumagalli et al. 2014).

Perhaps this is one of the reasons why most experiments relevant to upper mantle processes were conducted 
in simplified chemical compositions, so-called simple systems. Many experiments in systems $\mathrm{MgO}-\mathrm{Al}_{2} \mathrm{O}_{3}-\mathrm{SiO}_{2}$ (MacGregor 1974; Danckwerth and Newton 1978; Gasparik and Newton 1984), $\mathrm{CaO}-\mathrm{MgO}-\mathrm{Al}_{2} \mathrm{O}_{3}-\mathrm{SiO}_{2}$ (Kushiro et al. 1967; O'Hara et al. 1971; Akella 1976; Obata 1976; Jenkins and Newton 1979; Perkins and Newton 1980; O'Neill 1981; Gasparik 1984a, b; Sen 1985; Adam 1988; Gudfinnsson and Presnall 1996; Milholland and Presnall 1998; Walter et al. 2002) or $\mathrm{Na}_{2} \mathrm{O}-\mathrm{CaO}-\mathrm{MgO}-\mathrm{Al}_{2} \mathrm{O}_{3}-\mathrm{SiO}_{2}$ (Walter and Presnall 1994) have been performed to investigate processes in the upper mantle.

Figure 1a depicts experimentally derived phase relations in the system $\mathrm{CaO}-\mathrm{MgO}-\mathrm{Al}_{2} \mathrm{O}_{3}-\mathrm{SiO}_{2}$, based on reversal experiments of O'Neill (1981), Klemme and O'Neill (2000a), Adam (1988) and Milholland and Presnall (1998). See also a recent review paper (Fumagalli and Klemme 2015) for details on garnet to spinel peridotite reactions and related reactions in simple systems. The garnet to spinel peridotite transition in $\mathrm{CaO}-\mathrm{MgO}-\mathrm{Al}_{2} \mathrm{O}_{3}-\mathrm{SiO}_{2}$ is univariant and has a steep Clapeyron slope $(\mathrm{d} T / \mathrm{d} P)$ of about $40{ }^{\circ} \mathrm{C} /$ kbar (Walter et al. 2002) at temperatures above $1200{ }^{\circ} \mathrm{C}$.

However, it has been known for a long time that minor elements, especially $\mathrm{Cr}$ and $\mathrm{Fe}^{3+}$, have a strong effect of phase relations (O'Neill 1981; Nickel 1986; Webb and Wood 1986; Brey et al. 1999; Girnis and Brey 1999; Klemme and O'Neill 2000a; Klemme 2004; Borghini et al. 2009; Klemme et al. 2009). While Cr (and other minor elements) probably does not affect phase relations in the deeper upper or the lower mantle much, $\mathrm{Cr}$ is known to partition very unevenly between upper mantle mineral phases and it is well known to strongly stabilize spinel relative to garnet (O'Neill 1981; Asimow et al. 1995; Klemme 2004). This is particularly important for depleted mantle compositions (e.g. harzburgite), which are characterized by $\mathrm{Al}$ depletion and relatively high $\mathrm{Cr} /[\mathrm{Cr}+\mathrm{Al}]$ bulk compositions (Fig. 1b).

As mentioned above, experiments in Cr-rich bulk compositions are difficult to conduct and even more difficult to interpret, especially at temperatures $<1100{ }^{\circ} \mathrm{C}$ (very relevant for the uppermost mantle). However, the recent advances in thermodynamic modelling techniques and refinements of thermodynamic databases may help to investigate subsolidus phase relations in simple (e.g. Klemme 2004; Green et al. 2012) and complex (Asimow and Ghiorso 1998; Klemme et al. 2009, Ziberna et al. 2013, Jennings and Holland 2015) mantle compositions. In two previous papers, Klemme et al. (2009) and Ziberna et al. (2013) focused more on methods and calibration of a thermodynamic model for Cr-bearing mantle rocks, so the aim of this paper is to show how this thermodynamic model may be applied to investigate processes in the upper mantle.

As a case study, we used the compositions of mantle xenoliths from Pali-Aike, Patagonia (Skewes and Stern 1979; Stern et al. 1999; Wang et al. 2008) to address two different petrological problems. First, we calculate the response of density to changes in bulk compositions of subcontinental mantle, using different bulk compositions taken from the Pali-Aike mantle xenolith suite. Furthermore, we use phase equilibria calculations to explore possible $\mathrm{P}-\mathrm{T}$ paths recorded in the peridotite xenoliths from the same suite and to investigate kelyphite-forming reactions around garnets.

\section{Petrological background and sample selection}

The Pali-Aike volcanic field is located in Southern Patagonia and is the southernmost volcanic exposure of the Late

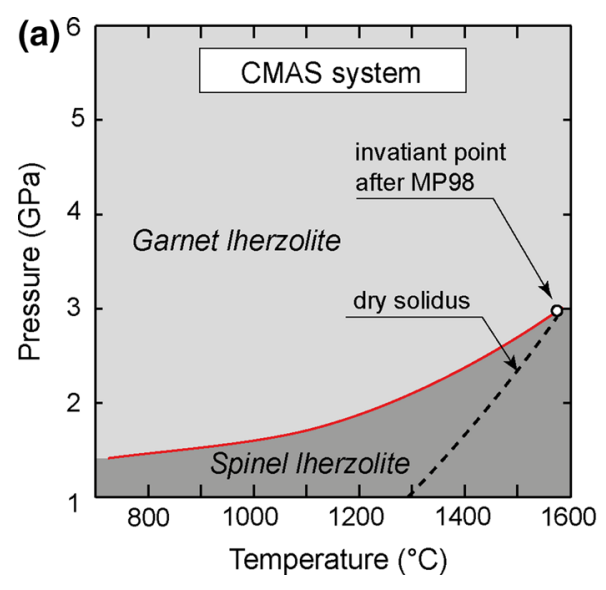

Fig. 1 Phase relations derived from a experiments in the system $\mathrm{CaO}-\mathrm{MgO}-\mathrm{Al}_{2} \mathrm{O}_{3}-\mathrm{SiO}_{2}$ (O'Neill 1981; Milholland and Presnall 1998-MP98; Klemme and O'Neill 2000b) and b thermodynamic calculations of Ziberna et al. (2013) for a depleted peridotite (man-

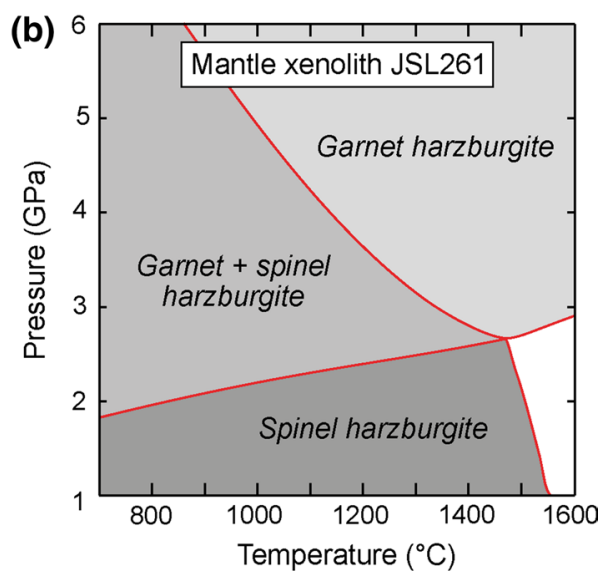

tle xenolith JSL261 from Van Achterbergh et al. 2001). In (b) olivine, orthopyroxene and clinopyroxene are always present in all the calculated mineral assemblages. The calculated mineral assemblage for the white field is spinel- and garnet-free 
Cenozoic Patagonian Plateau lavas (Fig. 2). It belongs to the Deseado Massif, a geologic unit that records different stages of rifting and subduction from the Neoproterozoic to the Early Cambrian (Pankhurst et al. 2006). Geological evidence and zircon ages suggest that the basement and the lithospheric mantle beneath Pali-Aike may be part of a Phanerozoic accretionary prism (Pankhurst et al. 2006). Two following tectonic events that affected this area were subsidence and sedimentation in Jurassic-Cretaceous and mantle upwelling in Neogene that produced, among others, the alkali basalts of the Pali-Aike volcanic field (Wang et al. 2008 and reference therein). The mantle xenoliths considered here have been sampled by these alkali basaltic lavas and pyroclastic rocks, which are Pliocene to Pleistocene in age (see D'Orazio et al. 2000 for a review in regard to dating of these rocks).

The majority of mantle xenoliths include harzburgites and lherzolites, which contain spinel, spinel + garnet or garnet as aluminous phases (Stern et al. 1999). Overall, this peridotitic suite shows a broad range of compositions, from fertile lherzolites to depleted harzburgites, with $\mathrm{Mg} \#=0.89-0.93, \mathrm{Al}_{2} \mathrm{O}_{3}=0.5-4.6 \mathrm{wt} \%, \mathrm{CaO}=0.4$ $4.0 \mathrm{wt} \%$ (see Fig. 5 in Stern et al. 1999 or our Table 1 for some representative compositions). This within-suite variability, together with the high abundance of vein-free and

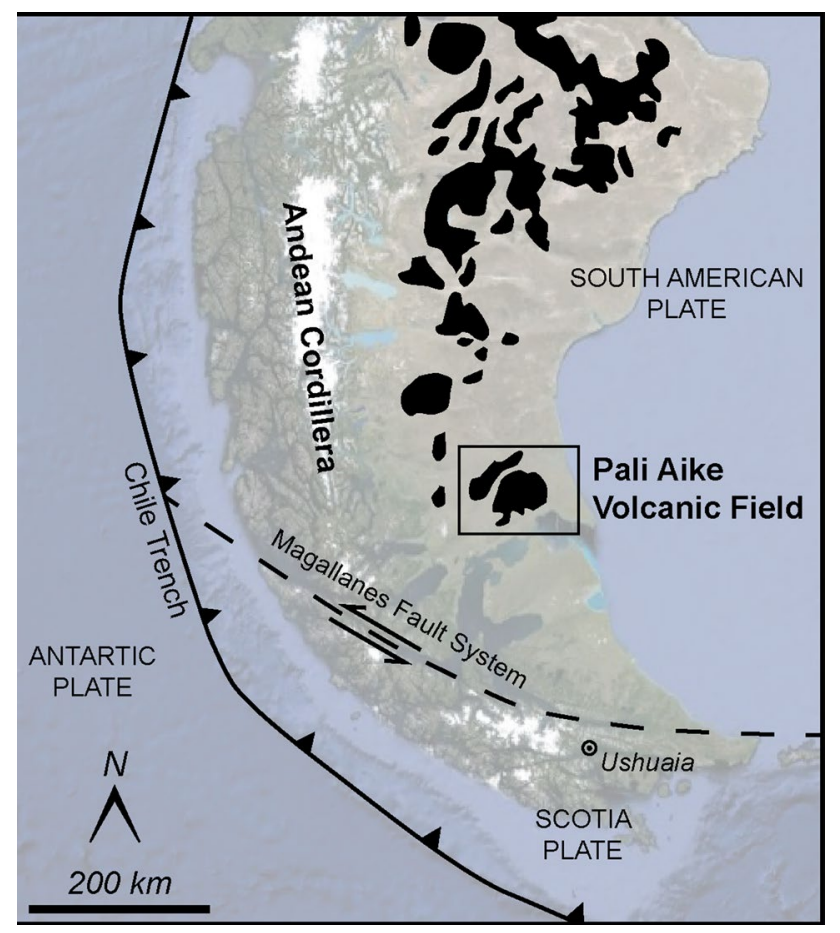

Fig. 2 Location map of the Pali-Aike Volcanic Field. The black areas represent the Cenozoic Patagonian Plateau lavas. Geologic units were taken from D'Orazio et al. (2000) and the background map is from Google Earth $^{\circledR}$, version 7.1.5.1557, imagery date 04/10/2013, eye altitude $1924.0 \mathrm{~km}$ unaltered samples with no evidence of melt infiltration and no hydrous minerals like amphibole or phlogopite (cf. Stern et al. 1999; Wang et al. 2008), makes this a good case study to test our thermodynamic model. Note that our model does not account either for melting or for the presence of fluids and volatile-bearing phases.

The selection of samples for phase equilibria calculations was based upon the petrological problems to be addressed. In all cases only compositions from xenoliths were selected that were described as fresh and vein-free (Stern et al. 1999). The first application of our model aims to investigate how the predicted density profiles change with changing bulk composition within the range recorded by mantle xenoliths. We therefore selected four representative peridotite compositions (LS1, PA3, TM16 and BN4; Table 1) that encompass the entire range of $\mathrm{Mg \#}, \mathrm{Cr} \#$ and Ca\# of the mantle xenolith suite from Pali-Aike (Stern et al. 1999). The second application aims to investigate the $\mathrm{P}-\mathrm{T}$ history of the mantle recorded in the xenoliths by comparing the textures, mineralogy and phase compositions of the xenoliths with the results of phase equilibria calculations. We therefore selected the samples that represent the mineralogical variability of the xenoliths and for which some descriptions on textures and compositional zoning are available in the literature. This selection included a spinel harzburgite (sample LS2), a spinel-garnet lherzolite (sample BN4) and a garnet lherzolite (sample LS33) (Table 1).

\section{Methods}

We used the Perple_X set of computer programs (Connolly 1990; Connolly and Petrini 2002), which enables to calculate mineral modes, mineral compositions and bulk physical properties (Connolly and Kerrick 2002) as a function of temperature pressure and, perhaps most importantly, bulk composition. Following Ziberna et al. (2013), we calculate subsolidus phase relations for several water- and carbonate-free bulk compositions, ranging from fertile lherzolite to depleted harzburgite (Table 1). The calculations were performed in the system $\mathrm{SiO}_{2}-\mathrm{Al}_{2} \mathrm{O}_{3}-\mathrm{Cr}_{2} \mathrm{O}_{3}-\mathrm{FeO}-\mathrm{MgO}-\mathrm{CaO}-\mathrm{Na}_{2} \mathrm{O}$.

The thermodynamic data used here for phase equilibria calculations in subsolidus mantle compositions are based on the internally consistent dataset of Holland and Powell (1998), complemented for the most relevant Cr-bearing phases in the upper mantle. Among the available sets of endmember properties and solution models for $\mathrm{Cr}$-bearing phases (e.g. Klemme et al. 2009; Ziberna et al. 2013, Jennings and Holland 2015), we adopted the model suggested by Klemme et al. (2009) which was later on refined by Ziberna et al. (2013). This model shows good agreement with the available experimental data in both $\mathrm{Cr}$-poor and $\mathrm{Cr}$-rich mantle 


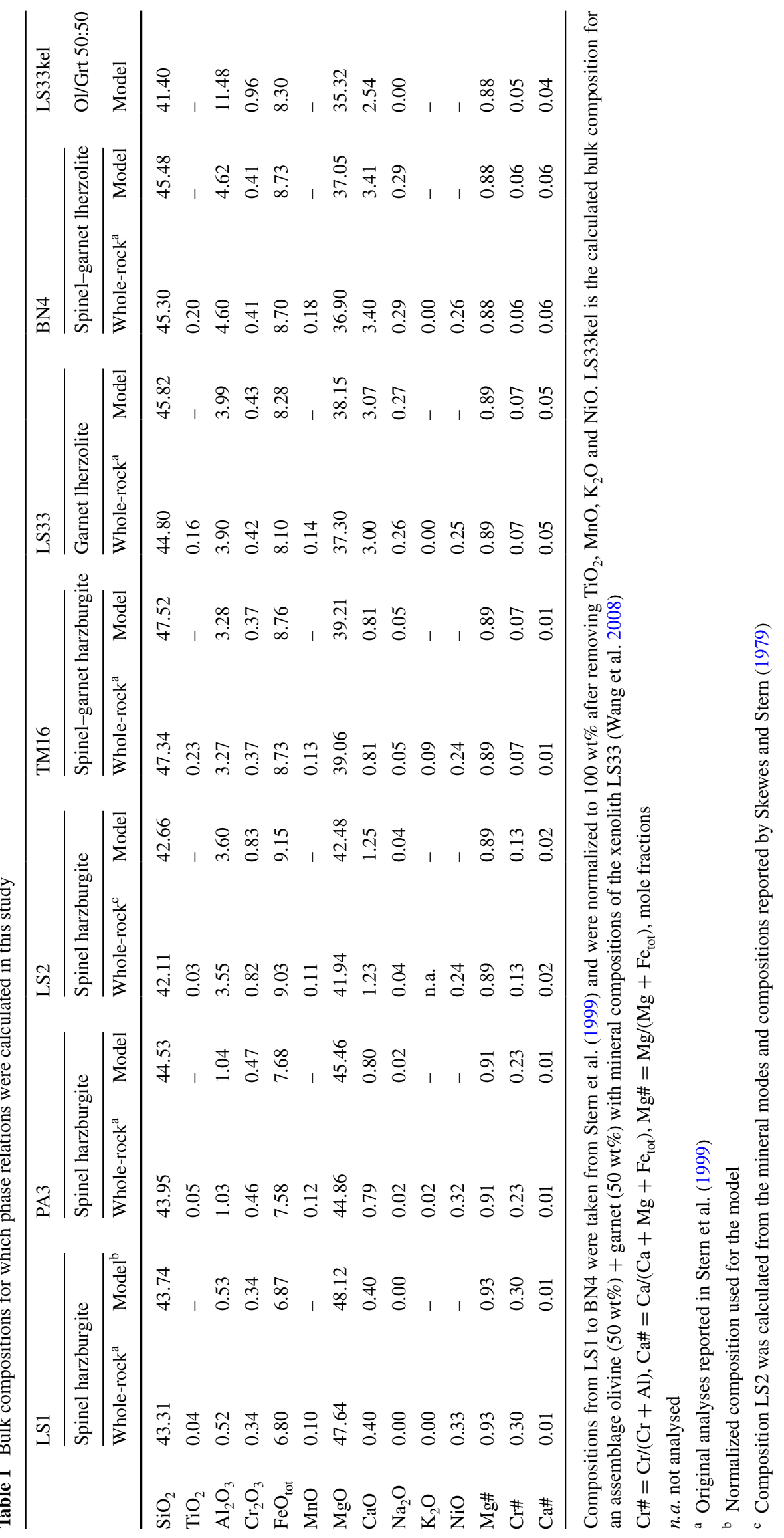


compositions (e.g. Nickel 1986; Webb and Wood 1986; Walter 1998; Brey et al. 1990, 1999, 2008) and is therefore considered to be more appropriate for an application to a set of natural mantle xenoliths such those from Pali-Aike (bulk $\mathrm{Cr} \#=0.05-0.30$ ). We would like to caution the reader that the values reported as enthalpies of formation in Table 2 of Klemme et al. (2009) and supplementary table of Ziberna et al. (2013) are actually free energies of formation and that the Cr-bearing clinopyroxene end-member used in the calculations is $\mathrm{CaCr}_{2} \mathrm{SiO}_{6}$ and not $\mathrm{MgCr}_{2} \mathrm{SiO}_{6}$. The entire set of end-member thermodynamic properties and solution models used for the calculations is available at http://www.perplex. eth.ch or can be obtained from the authors upon request.

\section{Density variations in the subcontinental mantle}

Understanding the vertical and lateral variation of density in the upper mantle is critical to our understanding of the tectonic and magmatic evolution of the lithosphere (Podladchikov et al. 1994; Kaus et al. 2005; Simon and Podladchikov 2008; Sakamaki et al. 2013). Moreover, a sound understanding of the nature of density variations is crucial to interpreting the structure of the mantle from geophysical information, such as seismic tomography or gravity anomalies (e.g. Stixrude and Lithgow-Bertelloni 2005; Afonso et al. 2013a, b). It is well known that density and seismic properties of mantle peridotites are related to the modes, compositions and elastic properties of their constituent minerals (i.e. olivine + orthopyroxene \pm clinopyroxene \pm aluminous phase) and melts, which in turn depend upon pressure, temperature and bulk composition (Ringwood 1975; Green and Liebermann 1976; Podladchikov et al. 1994; Suzuki and Othani 2003). Phase equilibria calculations based on thermodynamic data are commonly used to predict how phase relations and therefore the physical properties of rocks in the Earth's interior vary with depth (e.g. Connolly and Kerrick 2002; Stixrude and Lithgow-Bertelloni 2005; Afonso et al. 2008; Jones et al. 2014) (for a critical assessment on the application of phase equilibria calculations to rock physics and geodynamic modelling the reader is referred to Connolly 2009).

In this context, it is important to understand how bulk composition affects mineral phase assemblage and density in the uppermost mantle, which is known to be heterogeneous in both chemical and mineralogical composition, mainly due to localized metasomatism and melt extraction processes (Menzies and Hawkesworth 1987; Carlson et al. 2005; Pearson and Wittig 2008). Petrological studies of peridotite massifs and mantle xenoliths, integrated with geophysical observations and thermodynamic constraints, may help to understand how chemical composition, thermal state and density of the uppermost mantle are related to each other in a variety of geological settings. Thanks to the advances in computer programming and modelling techniques, it is now possible to integrate these methodologies in single, self-consistent models, which are able to predict even two- and threedimensional variations of density in the uppermost mantle (e.g. Afonso et al. 2008; Fullea et al. 2009).

In most previous studies, however, the calculations were made in Cr-free bulk composition (i.e. CFMAS or NCFMAS; Afonso et al. 2008; Fullea et al. 2009, 2010, 2012, 2014; Jones et al. 2014). Notably, the recent studies of Klemme et al. (2009) and Ziberna et al. (2013) show that phase relations in Cr-bearing, near-natural peridotite compositions change considerably with respect to the $\mathrm{Cr}$-free system. These changes may also affect the density profiles of the uppermost mantle peridotite. In this section, we set out to investigate whether and how the addition of $\mathrm{Cr}$ and resulting phase stability fields of spinel and garnet affect density profiles in a more realistic (i.e. Cr-bearing) uppermost mantle compositions in different thermal regimes.

The calculations for the four selected Pali-Aike peridotites (LS1, PA3, TM16, BN4; Table 1) were made for a P-T range $1.0-8.0 \mathrm{GPa}$ and $500-1400{ }^{\circ} \mathrm{C}$, and density profiles were calculated for two different geothermal gradients: $70 \mathrm{~mW} / \mathrm{m}^{2}$, which is similar to that predicted for the mantle beneath Pali-Aike (Stern et al. 1999; Wang et al. 2008), and $50 \mathrm{~mW} / \mathrm{m}^{2}$, which is representative of colder, off-craton, lithospheric sections. These gradients were derived from the preferred geotherm family of Hasterok and Chapman (2011), which are based on mantle xenolith thermobarometry, heat production measurements and tectonothermal constraints. Following Hasterok and Chapman (2011), here we also assume that the transition from a conductive to an adiabatic geotherm corresponds to the lithosphereasthenosphere boundary (LAB). This definition has no direct link to rheology, seismology or electrical conductivity, but is used here only to discuss the combining effects of phase transitions and changes in thermal gradient on the density profile. Moreover, it is important to emphasize that our calculations assume no volatile-bearing phases and only subsolidus conditions (and hence do not consider the possible presence of melt at the LAB or the presence of hydrous phases; cf. Green et al. 2010; Sakamaki et al. 2013; Stern et al. 2015).

Figure 3 depicts these geothermal gradients together with two examples of predicted density distribution in P-T space. In agreement with previous calculations (cf., Afonso et al. 2008; Simon and Podladchikov 2008), increasing depletion of the rock (i.e. decreasing $\mathrm{Al}_{2} \mathrm{O}_{3}, \mathrm{CaO}, \mathrm{NaO}$ and increasing $\mathrm{Mg \# )}$ leads to an overall decrease in density (Fig. 4a, c) in the mantle. This is mainly caused by bulk $\mathrm{Al}_{2} \mathrm{O}_{3}$, which increases the modes of spinel and garnet, the densest mineral phases in peridotite assemblages (Fig. 4b, d) (see also e.g. Wood and Yuen 1983; Lee 2003), and by bulk Mg\#, which relates to the Fe content in minerals (which in turn has a strong control on mineral densities; Lee 2003). However, here we show that the density profile across the spinel-to-garnet peridotite 


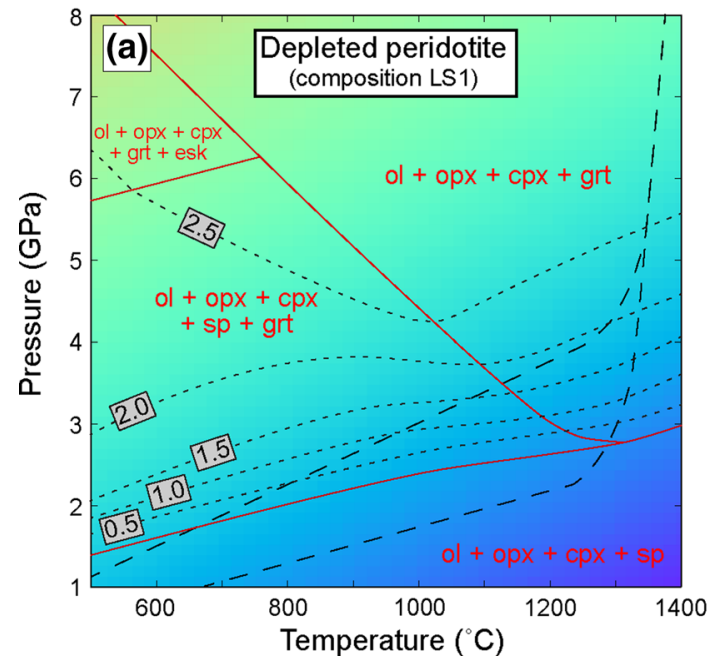

Fig. 3 Pressure-temperature diagram showing a colour map of the calculated density for the compositions a LS1 and b BN4 (mantle xenoliths from Pali-Aike, Stern et al. 1999). The two dashed curves represent a 50 (higher curve) and a $70 \mathrm{~mW} / \mathrm{m}^{2}$ (lower curve) conductive geotherms both joining the $1300{ }^{\circ} \mathrm{C}$ adiabat (Hasterok and Chapman 2011). The solid red curves delimit the stability fields predicted by the thermodynamic model (ol olivine, opx orthopyroxene, $c p x$

transition is not sharp and its shape strongly depends on bulk composition, other than geothermal gradient. If we consider a geotherm of $50 \mathrm{~mW} / \mathrm{m}^{2}$ and depleted compositions (LS1 and PA3 in Table 1), the density in the mantle remains virtually constant from ca. $30 \mathrm{~km}$ to ca. $120 \mathrm{~km}$ (Fig. 4a). In other words, the spinel-to-garnet transition is not reflected in the density profile of the mantle at all, with implications for interpreting seemingly contrasting geophysical datasets. However, things are very different if more fertile compositions are considered (TM16 and BN4 in Table 1). Here the density shows a relatively rapid increase when garnet becomes stable (at $\sim 40 \mathrm{~km}$ depths for these compositions and this geotherm). This increase becomes progressively less pronounced, until density returns to be virtually constant at $\sim 80 \mathrm{~km}$ (Fig. 4a, b).

In a mantle characterized by hot conductive geotherms $\left(70 \mathrm{~mW} / \mathrm{m}^{2}\right.$, Fig. $\left.4 \mathrm{c}, \mathrm{d}\right)$, the slope of the P-T gradient is such that the effect of temperature on the bulk density is higher than the effect of pressure (Fig. 3), leading to a decrease in density with depth in the lithosphere (Fig. 4c). For depleted compositions (LS1, PA3) and identical geothermal gradients, the spinel-garnet transition is very narrow and occurs in proximity to the LAB (Fig. 3a). The rapid change of temperature gradient at the LAB and the low modes of spinel and garnet for these compositions hide the effect of the spinel-garnet transition on the density profile. For more fertile composition (BN4), the conductive geotherm enters the spinel + garnet stability field long before the LAB (Fig. 3b). The rapid increase in garnet modes (Fig. 4d) therefore leads to a relative increase in density with respect to the other

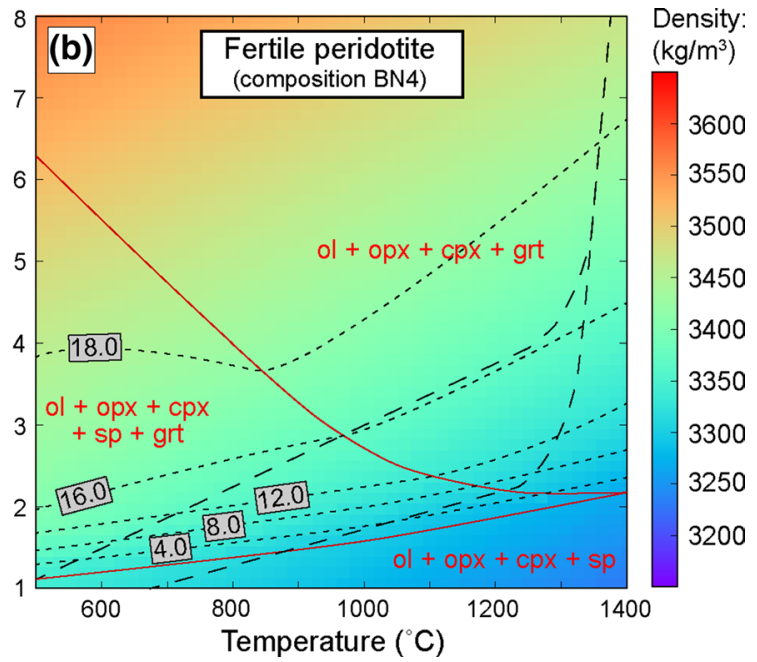

clinopyroxene, grt garnet, $s p$ spinel, esk eskolaite). It is worth noting that garnet modes (isopleths marked by grey squares) have the major control on density variations across the spinel-garnet transition. The smoother density variation at the spinel-garnet transition in (a) is indeed related to the very low modes of garnet $(<3.0 \mathrm{wt} \%)$ for composition BN4 (see text)

compositions. Moreover, the interaction of temperature gradient and garnet and spinel mode variations result in a smooth density profile across the LAB (Fig. 4c), which in fact overlaps with the spinel-garnet transition.

The density profiles shown here are different from the results of recent geodynamical modelling studies, which show in all compositions a step-like change in density at the spinel-garnet transition (c.f. Fullea et al. 2014). The differences can be easily ascribed to (1) the absence of $\mathrm{Cr}$ in the Fullea et al. (2014) thermodynamic model (Cr is known to broaden the spinel + garnet stability field and, therefore, smooths the density contrast between spinel and garnet peridotites) and (2) the absence of depleted (e.g. poor in $\mathrm{Al}_{2} \mathrm{O}_{3}$ and relatively enriched in $\mathrm{Cr}_{2} \mathrm{O}_{3}$ ) or harzburgitic bulk compositions in their calculations. A step forward in the application of these integrated geophysical-petrological methodologies would be, therefore, to extend the thermodynamic model used by Fullea et al. (2014) to Cr-bearing systems.

In summary, our results show how the spinel-garnet transition affects the density variations in realistic nearnatural, and Cr-bearing, upper mantle compositions. It is worth noting that in a depleted mantle (bulk $\mathrm{Cr} \#>0.20$ ) the spinel-garnet transition is not reflected in the density profiles, while in a fertile mantle the transition clearly affects the density profile. This contrast can be explained by the lower bulk $\mathrm{Cr} \#$ and higher $\mathrm{Al}_{2} \mathrm{O}_{3}$ content of the peridotites typical in the fertile mantle. The former decreases the width of the spinel-garnet transition, while the latter increases 

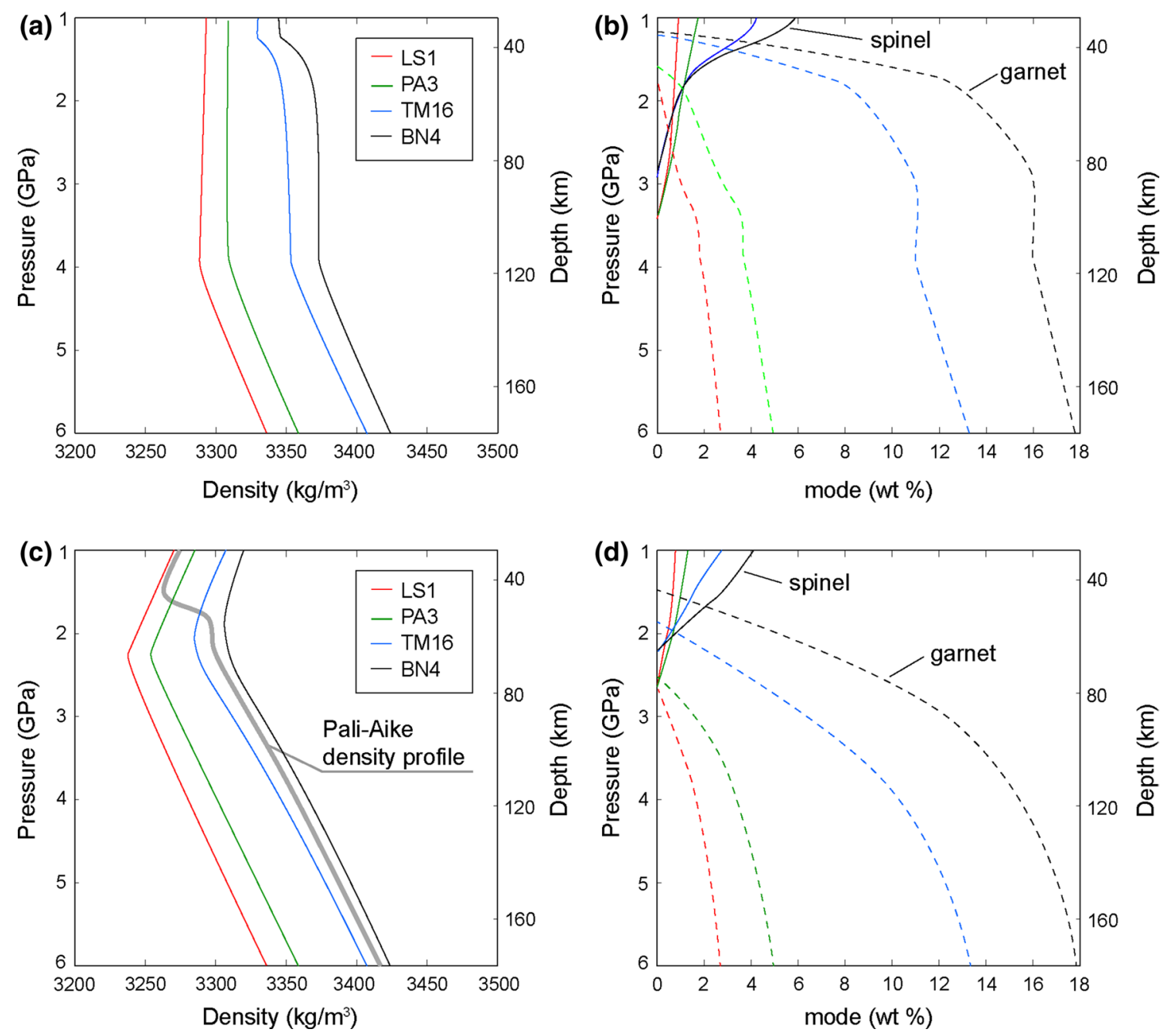

Fig. 4 Calculated density profiles and garnet (dashed lines) and spinel (solid lines) modes for some representative Pali-Aike peridotite compositions (Table 1) along a $50 \mathrm{~mW} / \mathrm{m}^{2}$ steady state geotherm (a, b) and a $70 \mathrm{~mW} / \mathrm{m}^{2}$ geotherm $(\mathbf{c}, \mathbf{d})$. The solid grey curve in (c)

represents a possible density profile beneath Pali-Aike based on the compositional layering observed by (Stern et al. 1999). For sake of simplicity, the depth values shown on the right axes were calculated assuming constant density (i.e. depth $=\mathrm{P}(\mathrm{GPa}) 9.8 \mathrm{~m} / \mathrm{s}^{2} \cdot 3.0 \mathrm{~kg} / \mathrm{cm}^{3}$ )

the modes of spinel and garnet, which therefore will have a stronger control on the density variations. In case of hot geotherms (ca. $70 \mathrm{~mW} / \mathrm{m}^{2}$ ), the spinel-garnet transition may overlap with the LAB. Such results may also help to interpret the origin of the Hales discontinuity or Hales gradient zone, a seismic impedance increase commonly attributed to the spinel-garnet transition (Hales 1969; Revenaugh and Jordan 1991; Ayarza et al. 2010).

The Pali-Aike lithospheric mantle is inferred to be composed by depleted harzburgites at shallow depths (ca. 30-60 km) and fertile lherzolites at greater depths (ca. 50-90 km; Stern et al. 1999). A possible origin for this layering is magma extraction in a mid-oceanic ridge setting occurred during the late Proterozoic, prior to the accretion of this mantle section to the western margin of Gondwanaland during the Palaeozoic (Stern et al. 1999). An estimated

density profile for such a layered mantle is represented in Fig. 4c. Despite this being a simplified stratigraphic model, it shows how the compositional layering of the lithospheric mantle, which typically varies from depleted to fertile compositions, may have a strong effect on density structure of the upper mantle.

\section{Evolution of garnet-spinel peridotites from Patagonia}

Studying texture, mineralogy and geochemistry of mantle xenoliths is important if we are to constrain the nature and the evolution of the lithospheric mantle. The Pali-Aike mantle xenoliths suite includes lherzolites, harzburgites and minor pyroxenites that show a range of textural and 
mineralogical variations, which potentially record several processes that occurred in the mantle (Skewes and Stern 1979; Stern et al. 1999; Wang et al. 2008). Stern et al. (1999) and Wang et al. (2008) used this xenoliths suite to interpret the geochemical and tectonic history of the mantle beneath the southernmost South America. They suggested that the mantle section beneath Pali-Aike underwent two different tectonothermal events: (1) early cooling and/ or pressure increase (i.e. accretion) followed by (2) more recent heating and decompression (Stern et al. 1999; Wang et al. 2008).

Based on Stern et al. (1999), there are two pieces of evidence that support an early cooling and pressure increase. Firstly, spinel in spinel + garnet peridotites (e.g. BN4 in Table 1) is commonly fully enclosed in garnet, which led Stern et al. (1999) to interpret the spinels as relics of the reaction spinel + pyroxene $=$ garnet + olivine. Secondly, in low-T spinel peridotites $\left(<970{ }^{\circ} \mathrm{C}\right.$; e.g. LS2 in Table 1) the core of orthopyroxenes is homogeneous but close to the rim $\mathrm{Al}$ and $\mathrm{Ca}$ decrease. Similar but less prominent zoning was also observed for clinopyroxenes (no data are available instead for spinel and garnet). Based on consideration on element diffusion scales and thermometric estimates, Stern et al. (1999) interpret this zonation as a result of cooling.

Stern et al. (1999) discussed two pieces of evidence also for the scenario of recent heating and decompression. Firstly, the high-T spinel and garnet peridotites contain orthopyroxene showing $\mathrm{Al}$ and $\mathrm{Ca}$ increase progressively from core to rim. In the garnet lherzolites recording the highest temperatures (e.g. LS33 in Table 1), the zonation in $\mathrm{Ca}$ is absent, which was interpreted as an effect of more rapid element diffusion at higher temperature (Stern et al. 1999). Then, garnet is often surrounded by a spinel + pyroxenes ( + occasional amphibole) kelyphitic rim, which is a reaction product commonly interpreted to be driven by heating and/or decompression (e.g. Godard and Martin 2000; Obata 2011).

Here we tested their proposed scenarios by calculating phase relations for the three selected peridotitic compositions (BN4, LS2 and LS33 in Table 1), which allowed investigating the effect of temperature or pressure variation on mineral modes and compositions. We focused in particular on the reaction spinel-to-garnet peridotite and on the formation of kelyphitic rims around garnet.

Figure 5 shows how the calculated modes of the peridotitic assemblage and $\mathrm{Al}_{2} \mathrm{O}_{3}$ content of pyroxenes vary with temperature (at constant pressure) and with pressure (at constant temperature). Generally, the model predicts that at $\mathrm{P}-\mathrm{T}$ conditions where both garnet and spinel are stable, a temperature decrease results in a pronounced increase in modal garnet and decrease in orthopyroxene. Less pronounced decrease in modal clinopyroxene and increase in spinel are also evident (Fig. 5c, e). This is in line with the well-known reaction describing the spinel-to-garnet transition: spinel + pyroxene $=$ garnet + olivine, with the reaction products being stabilized at lower temperatures (Green and Ringwood 1967; O'Neill 1981; Klemme and O'Neill 2000b). $\mathrm{Al}_{2} \mathrm{O}_{3}$ contents in pyroxenes decrease constantly with decreasing temperature and generally increase with decreasing pressure, in accordance with experimental observations (cf. Green and Ringwood 1970; Nickel 1989; Brey et al. 1990, 2008). However, the $\mathrm{P}$ dependence of $\mathrm{Al}_{2} \mathrm{O}_{3}$ in pyroxenes is not linear. $\mathrm{Al}_{2} \mathrm{O}_{3}$ is constant in the spinel stability field, it steeply decreases with pressure in the spinel + garnet field and then smoothes at higher pressures where spinel is not stable (Fig. 5b, d, f), and the reaction $\mathrm{MgAl}_{2} \mathrm{SiO}_{6}+\mathrm{Mg}_{2} \mathrm{Si}_{2} \mathrm{O}_{6}=\mathrm{Mg}_{3} \mathrm{Al}_{2} \mathrm{Si}_{3} \mathrm{O}_{12}$ (Green and Ringwood 1970) is not as significant as at high temperatures. It is important to note, however, that the $\mathrm{Al}_{2} \mathrm{O}_{3}$ contents in clinopyroxenes may be slightly overestimated by our model, as they generally show slightly higher values relative to the available phase equilibria experiments at comparable temperatures (e.g. Green and Ringwood 1970; Nickel 1989; Brey et al. 1990, 2008). Further development of the model should include a better thermodynamic mixing model and better end-member data for the tschermakite end-members of clinopyroxene solid solution.

\section{From spinel to garnet peridotites: cooling, pressure increase or both?}

Based on the textural evidence of the reaction spinel + pyroxene $\rightarrow$ garnet + olivine, Stern et al. (1999) suggested early cooling of the mantle, perhaps in the Jurassic period (for details refer to Stern et al. 1999). This scenario is supported by $\mathrm{Ca}$ decrease in orthopyroxenes from core to rim in low-T spinel peridotites, which correspond to a $\mathrm{T}$ decrease of about $150-200{ }^{\circ} \mathrm{C}$ when applying the Ca-in-opx thermometer of Brey and Köhler (1990). To explain the occurrence of relic spinel in garnet peridotites, Wang et al. (2008) on the other hand suggested a pressure increase driven by subduction or accretion of oceanic lithosphere, but they do not provide any petrological evidence to support this hypothesis.

To test the scenarios inferred by Stern et al. (1999) and Wang et al. (2008) on low-T peridotites (here represented by the composition LS2), we considered the cooling to be isobaric, with the fixed pressure values corresponding to the thermobarometric estimates of Stern et al. (1999) (see their Figs. 2 and 9). Given the likely uncertainties of these estimates (ca. $30-80{ }^{\circ} \mathrm{C}$ and $0.2-0.4 \mathrm{GPa}$ depending on the adopted formulation and only if equilibrium of the assemblage is assumed; see Nimis and Grütter 2010 for a review), these values were used just as an approximate estimation of the P-T conditions of the xenolith, which were sufficient enough for the purpose of modelling. For 

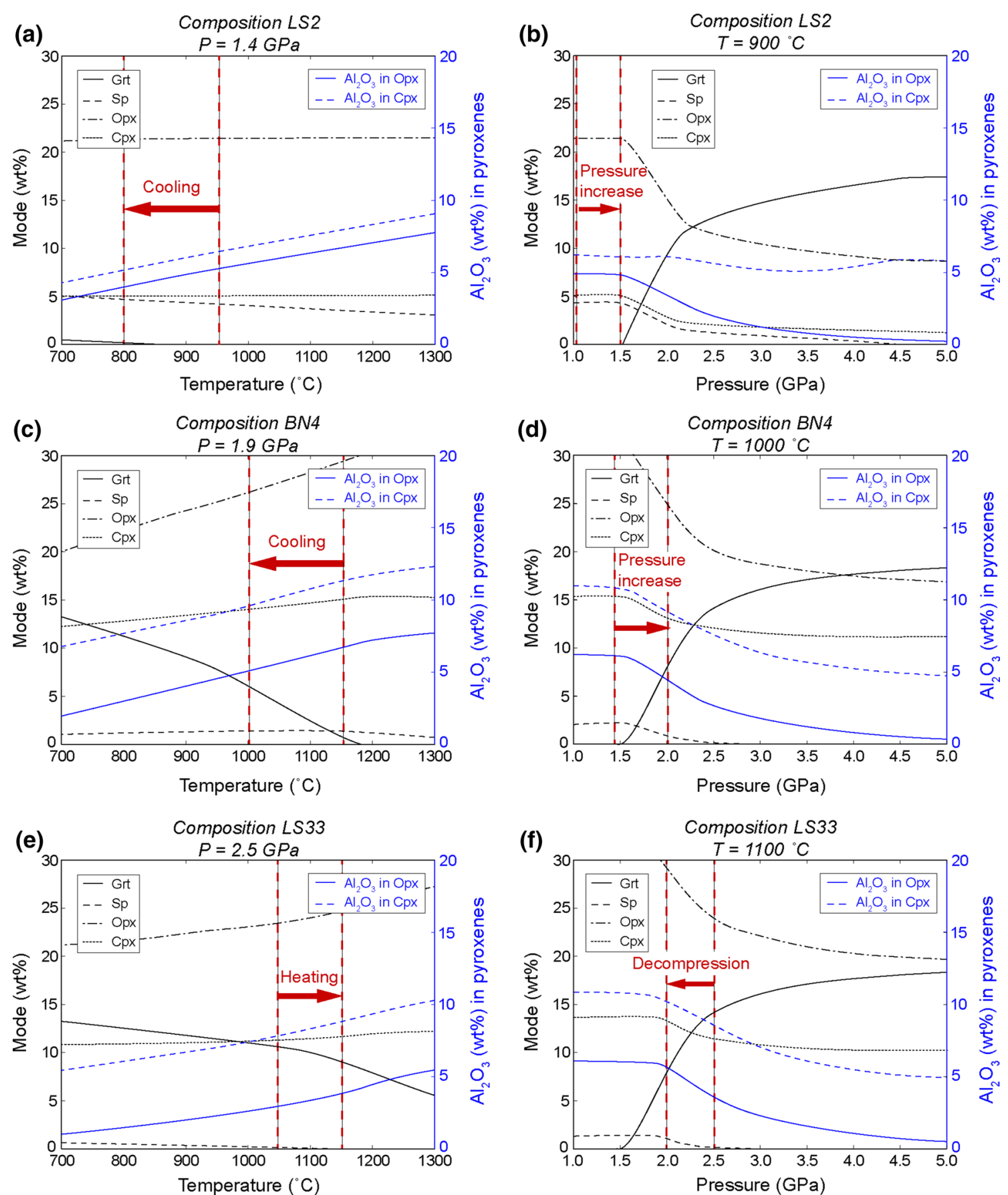

Fig. 5 Temperature and pressure dependence of mineral modes and $\mathrm{Al}_{2} \mathrm{O}_{3}$ wt $\%$ in ortho- and clinopyroxenes calculated for three different Pali-Aike mantle compositions. LS2 is a spinel-harzburgite, BN4 a garnet-spinel lherzolite and LS33 a garnet lherzolite xenolith (Stern et al. 1999). The thermobarometric estimates for each xenolith,

reported in Stern et al. (1999), were used as reference $\mathrm{P}$ and $\mathrm{T}$ values for the calculation. The red arrows show the possible $\mathrm{P}-\mathrm{T}$ evolution paths based on the thermobarometric estimates of the mantle xenoliths

the composition LS2, the predicted mineralogy at the estimated P-T conditions of the xenolith corresponds to a spinel harzburgite (Figs. 5a,b). A temperature decrease from 950 to $800{ }^{\circ} \mathrm{C}$ (as estimated by Stern et al., 1999 for the sample LS2) does not affect the mineral assemblage and

results in a progressive decrease of $\mathrm{Al}_{2} \mathrm{O}_{3}$ content in pyroxenes (Fig. 5a). Consistently, the xenolith LS2 (1) is a spinel harzburgite, (2) shows no textural evidence of replacement reactions and (3) contains orthopyroxenes characterized by decreasing $\mathrm{Al}_{2} \mathrm{O}_{3}$ from core-to-rim (Stern et al. 1999). No 
data about zoning of clinopyroxenes are reported by Stern et al. (1999) or Wang et al. (2008). On the other hand, a pressure increase in the range 1.0-2.0 GPa, a typical range for spinel peridotites, results in $\mathrm{Al}_{2} \mathrm{O}_{3}$ decrease in orthopyroxene only when garnet become part of the assemblage. Given that there is no evidence of garnet in this xenolith, a pressure increase at constant temperature is therefore not supported by our calculations.

For the xenolith BN4, which was selected here to represent the Pali-Aike garnet-spinel lherzolites (with spinel present as inclusions in garnets), Stern et al. (1999) estimated the pressure and temperature to be $1.9 \mathrm{GPa}$ and $1000{ }^{\circ} \mathrm{C}$. If a temperature decrease from 1150 to $1000{ }^{\circ} \mathrm{C}$ is considered, the model predicts a transition from spinel to spinel-garnet peridotite, with garnet modes being ca. 6-7 wt \% and spinel modes ca. $1-2 \mathrm{wt} \%$ at about $1000{ }^{\circ} \mathrm{C}$ (Fig. 5c). This is in good agreement with the mineral assemblage in the xenolith BN4 and the textural evidence of the reaction spinel + pyroxene $=$ garnet + olivine observed for this and other garnet-spinel peridotites xenoliths from Pali-Aike. In this case, also a pressure increase from ca. 1.5 to $2.0 \mathrm{GPa}$ would produce the same mineralogical variation (Fig. 5d).

Phase equilibria calculations therefore indicate that a temperature decrease of about $150{ }^{\circ} \mathrm{C}$ best reproduces the mineral assemblage and mineral zoning observed in the low-temperature spinel peridotites and garnet-spinel lherzolites. Although minor pressure variations may have also occurred, our thermodynamic modelling results indicate that progressive cooling from Palaeozoic to late Cenozoic may be the most likely scenario in this portion of the PaliAike mantle section.

\section{Kelyphite formation around garnets: heating, decompression or both?}

The formation of kelyphite rims is often explained as a reaction of garnet and other mantle minerals with volatilebearing infiltrating agents derived from the host magma (Dawson 1980; Hunter and Taylor 1982; Garvie and Robinson 1984). However, here we focus on an alternative kelyphite-forming process, which is linked to $\mathrm{P}-\mathrm{T}$ change (Reid and Dawson 1972; Godard and Martin 2000), as suggested for the Pali-Aike garnet peridotites (e.g. Stern et al. 1999).

Based on element diffusion systematics and thermobarometry, Stern et al. (1999) suggested that the high-T garnet peridotites from Pali-Aike recorded only a last stage of heating and decompression related to the quaternary magmatism that sampled the xenoliths. They suggested that the core-to-rim $\mathrm{CaO}$ and $\mathrm{Al}_{2} \mathrm{O}_{3}$ increase in orthopyroxenes and the occurrence of kelyphitic rims surrounding garnets support this scenario. The garnet lherzolite xenolith LS33 was selected here as representative for our calculations. Our model shows that heating from about $1050-1150{ }^{\circ} \mathrm{C}$ (the temperature increase estimated by Stern et al. 1999) results in a gradual decrease in modal garnet, increase in orthopyroxene and clinopyroxene and increase in $\mathrm{Al}_{2} \mathrm{O}_{3}$ in orthopyroxene (Fig. 5e). The latter is in agreement with the observed zoning of the primary orthopyroxenes in the xenoliths. A pressure decrease from 2.5 to $2.0 \mathrm{GPa}$ would result in a similar mineralogical variation, with garnet modes decreasing from 15 to $8 \mathrm{wt} \%$ (Fig. 5f).

The development of kelyphitic rims around garnets, which are typically composed of orthopyroxene + clinopyroxene + spinel, could be, at first approximation, modelled by our predicted decrease in garnet and increase in pyroxenes modes shown in Fig. 5e, f, driven by either heating or decompression. However, kelyphites around garnets in peridotites have been interpreted to be a product of the reaction between garnet and the surrounding olivine or orthopyroxene (Mukhopadhyay 1991; Godard and Martin 2000; Obata 2011), being therefore a reaction occurring in a discrete volume of the peridotite. Obata (2011) in particular, reported the textural evidence for such localized reactions. This means that the system to be considered for phase equilibria calculations should not be the bulk peridotite, but rather a local domain enclosing the garnet-olivine interface.

Therefore, to test the conditions of kelyphite formation in the case of garnet completely surrounded by olivine, we constructed a composition from the modal proportions $50 \%$ olivine and $50 \%$ garnet using the mineral composition reported for the sample LS33 (Wang et al. 2008). The resulting bulk composition is reported in Table 1 (LS33kel), and the results of the calculations are reported in Fig. 6.

The calculated mineralogical and compositional variations in Fig. 6 clearly show a predominant effect of pressure on the mineral assemblage. At $\mathrm{T}=1100{ }^{\circ} \mathrm{C}$ and $P>2.5$ $\mathrm{GPa}$, garnet + olivine is the stable assemblage, in accordance with the xenolith evidence. Considering isothermal decompression, garnet modes rapidly decrease starting from ca. 2.3 GPa, while orthopyroxene, clinopyroxene and spinel modes increase, consistently with the typical assemblage found in kelyphites. Moreover, the variation of mineral modes agrees well with what is commonly observed in kelyphites, i.e. orthopyroxene being the dominant phase, while clinopyroxene and spinel modes are lower (Obata 2011). Furthermore, the very high $\mathrm{Al}_{2} \mathrm{O}_{3}$ content typically observed in pyroxenes in kelyphites (5-15 wt\%; cf. Mukhopadhyay 1991; Foley et al. 2006; Špaček et al. 2013) is also reproduced by our model (Fig. 6b).

Similar results were obtained considering different bulk compositions constructed from garnets and olivines from the other xenoliths from Pali-Aike, and different $\mathrm{T}$ and $\mathrm{P}$ values for the isothermal and isobaric calculations, respectively. The calculations therefore show how the formation 


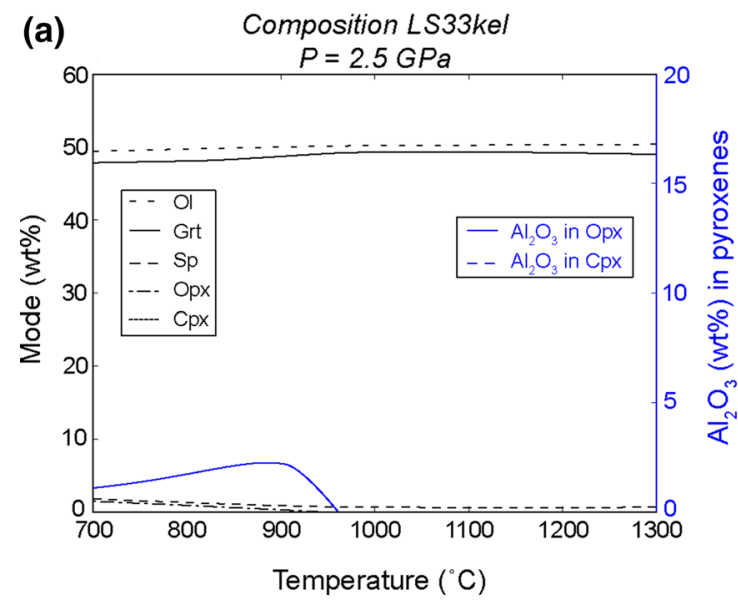

Fig. 6 Calculated variations of mineral modes and $\mathrm{Al}_{2} \mathrm{O}_{3}$ in pyroxenes for a system representing a garnet-olivine domain (i.e. $50 \%$ olivine, $50 \%$ garnet, composition LS33kel in Table 1), using the mineral compositions of the sample LS33 from Wang et al. (2008). At

of kelyphites at the garnet-olivine interface is most likely related to decompression and can be isochemical (i.e. does not require additional components from metasomatic melts or fluids).

\section{Conclusions}

We present results from phase equilibria calculations in near-natural, Cr-bearing peridotitic compositions representing the Pali-Aike mantle. The results show that the interplay between thermal gradient and bulk composition exerts the major control on the density variation in the lithospheric mantle. Focusing on shallower mantle around the spinelgarnet transition, our results indicate that (1) in depleted bulk compositions (i.e. harzburgite) the density profile is such that the spinel-garnet transition does not show in the density profile and (2) in fertile bulk compositions (i.e. lherzolite) the density change across the garnet spinel transition on a warm geotherm is not abrupt but rather more gradual and may overlap with the density change related to the lithosphere-asthenosphere transition.

The comparison between the mineral assemblages in the mantle xenoliths and the calculated phase relations for the same rocks were used to infer the P-T evolution of the mantle beneath Pali-Aike. The results indicate that the spinel + garnet peridotite xenoliths, which exhibit textural evidence of the reaction spinel + pyroxene $=$ garnet + olivine, are more likely a result of cooling rather than pressure increase. In addition, phase equilibria calculations showed that the kelyphitic rims around garnets in peridotites may form simply due to an isochemical reaction driven by decompression rather than heating.

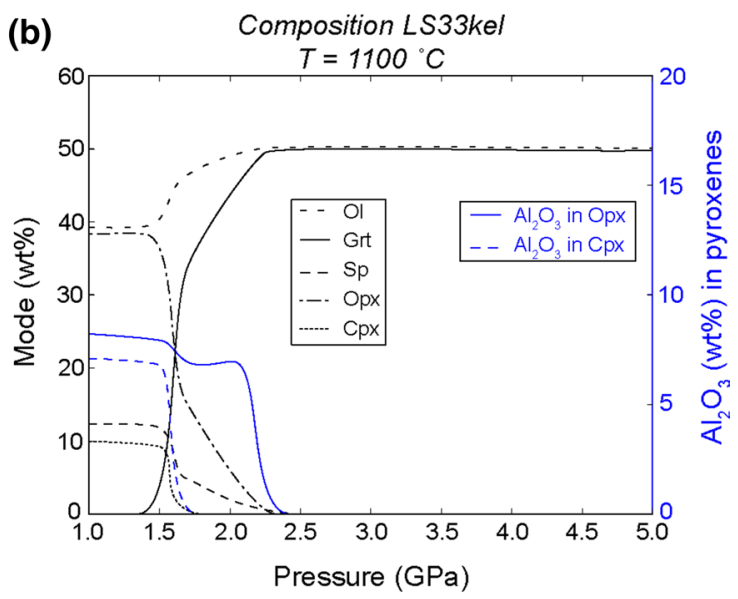

conditions $2.5 \mathrm{GPa}$ and $700-1300{ }^{\circ} \mathrm{C}(\mathbf{a})$, the model does not predict clinopyroxene to be stable, while orthopyroxene is stable until ca. $900{ }^{\circ} \mathrm{C}$ and shows a progressive increase in $\mathrm{Al}$ with temperature

Acknowledgments Our thanks go to Prof. DH Green and an anonymous reviewer for detailed, critical and constructive comments, which helped to improve the manuscript substantially.

Open Access This article is distributed under the terms of the Creative Commons Attribution 4.0 International License (http://creativecommons.org/licenses/by/4.0/), which permits unrestricted use, distribution, and reproduction in any medium, provided you give appropriate credit to the original author(s) and the source, provide a link to the Creative Commons license, and indicate if changes were made.

\section{References}

Adam J (1988) Dry, hydrous, and $\mathrm{CO}_{2}$-bearing liquidus phase relationships in the cmas system at $28 \mathrm{~Kb}$, and their bearing on the origin of alkali basalts. J Geol 96:709-719

Afonso JC, Fernàndez M, Ranalli G, Griffin WL, Connolly JAD (2008) Integrated geophysical-petrological modeling of the lithosphere and sublithospheric upper mantle: methodology and applications. Geochem Geophys Geosys. doi:10.1029/200 $7 \mathrm{gc} 001834$

Afonso JC, Fullea J, Griffin WL, Yang Y, Jones AGD, Connolly JA, O'Reilly SY (2013a) 3-D multiobservable probabilistic inversion for the compositional and thermal structure of the lithosphere and upper mantle. I: a priori petrological information and geophysical observables. J Geophys Res Solid Earth 118:2586-2617

Afonso JC, Fullea J, Yang Y, Connolly JA, Jones AG (2013b) ) 3-D multi-observable probabilistic inversion for the compositional and thermal structure of the lithosphere and upper mantle. II: general methodology and resolution analysis. J Geophys Res Solid Earth 118:1650-1676

Akella J (1976) Garnet pyroxene equilibria in the system $\mathrm{CaSiO}_{3}-$ $\mathrm{MgSiO}_{3}-\mathrm{Al}_{2} \mathrm{O}_{3}$ and in natural mineral mixture. Am Mineral 61:589-598

Asimow PD, Ghiorso MS (1998) Algorithmic modifications extending MELTS to calculate subsolidus phase relations. Am Mineral 83:1127-1132 
Asimow PD, Hirschmann MM, Ghiorso MS, O'Hara MJ, Stolper EM (1995) The effect of pressure-induced solid-solid phase transitions on decompression melting of the mantle. Geochim Cosmochim Acta 59:4489-4506

Ayarza P, Palomeras I, Carbonell R, Afonso JC, Simancas F (2010) A wide-angle upper mantle reflector in SW Iberia: some constraints on its nature. Phys Earth Planet Inter 181:88-102

Borghini G, Fumagalli P, Rampone E (2009) The stability of plagioclase in the upper mantle: subsolidus experiments on fertile and depleted lherzolite. J Petrol 51:229-254

Brey GP, Köhler T (1990) Geothermobarometry in four-phase lherzolites II. New thermobarometers, and practical assessment of existing thermobarometers. J Petrol 31:1353-1378

Brey G, Köhler T, Nickel K (1990) Geothermobarometry in fourphase lherzolites I. Experimental results from 10 to $60 \mathrm{~kb}$. J Petrol 31:1313-1352

Brey GP, Doroshev AM, Girnis AV, Turkin AI (1999) Garnet-spinelolivine-orthopyroxene equilibria in the $\mathrm{FeO}-\mathrm{MgO}-\mathrm{Al}_{2} \mathrm{O}_{3}-\mathrm{SiO}_{2}-$ $\mathrm{Cr}_{2} \mathrm{O}_{3}$ system: I. Composition and molar volumes of minerals. Eur J Mineral 11:599-617

Brey GP, Bulatov VK, Girnis V (2008) Geobarometry for Peridotites: experiments in simple and natural systems from 6 to $10 \mathrm{GPa}$. J Petrol 49:3-24

Carlson RW, Pearson DG, James DE (2005) Physical, chemical, and chronological characteristics of continental mantle. Rev Geophys 43:1-24

Connolly JAD (1990) Multivariable phase-diagrams-an algorithm based on generalized thermodynamics. Am J Sci 290:666-718

Connolly JAD (2009) The geodynamic equation of state: What and how. Geochem Geophys Geosys 10. doi:10.1029/2009GC002540

Connolly JAD, Kerrick DM (2002) Metamorphic controls on seismic velocity of subducted oceanic crust at $100-250 \mathrm{~km}$ depth. Earth Planet Sci Lett 204:61-74

Connolly JAD, Petrini K (2002) An automated strategy for calculation of phase diagram sections and retrieval of rock properties as a function of physical conditions. J Metamorph Geol 20:697-708

Danckwerth PA, Newton RC (1978) Experimental determination of the spinel peridotite to garnet peridotite reaction in the system $\mathrm{MgO}-\mathrm{Al}_{2} \mathrm{O}_{3}-\mathrm{SiO}_{2}$ in the range $900-1100 \mathrm{C}$ and $\mathrm{Al}_{2} \mathrm{O}_{3}$ isopleths of enstatite in the spinel field. Contrib Mineral Petrol 66:189-201

Dawson JB (1980) Kimberlites and their xenoliths. Springer, Berlin

D’Orazio M, Agostini S, Mazzarini F, Innocenti F, Manetti P, Haller MJ, Lahsen A (2000) The Pali Aike volcanic field, Patagonia: slab-window magmatism near the tip of South America. Tectonophysics 321:407-427

Falloon TJ, Danyushevsky LV, Green DH (2001) Peridotite melting at $1 \mathrm{GPa}$ : reversal experiments on partial melt compositions produced by peridotite-basalt sandwich experiments. J Petrol 42:2363-2390

Foley SF, Andronikov AV, Jacob DE, Melzer S (2006) Evidence from Antarctic mantle peridotite xenoliths for changes in mineralogy, geochemistry and geothermal gradients beneath a developing rift. Geochim Cosmochim Acta 70:3096-3120

Fullea J, Afonso JC, Connolly JAD, Fernandez M, Garcia-Castellanos D, Zeyen H (2009) LitMod3D: an interactive 3-D software to model the thermal, compositional, density, seismological, and rheological structure of the lithosphere and sublithospheric upper mantle. Geochem Geophys Geosys. doi:10.1029/2009GC002391

Fullea J, Fernandez M, Afonso JC, Verges J, Zeyen H (2010) The structure and evolution of the lithosphere-asthenosphere boundary beneath the Atlantic-Mediterranean Transition Region. Lithos 120:74-95

Fullea J, Lebedev S, Agius MR, Jones AG, Afonso JC (2012) Lithospheric structure in the Baikal-central Mongolia region from integrated geophysical-petrological inversion of surface-wave data and topographic elevation. Geochem Geophys Geosys. doi :10.1029/2012GC004138

Fullea J, Muller MR, Jones AG, Afonso JC (2014) The lithosphereasthenosphere system beneath Ireland from integrated geophysical-petrological modeling II: 3D thermal and compositional structure. Lithos 189:49-64

Fumagalli P, Klemme S (2015) Mineralogy of the earth: phase transitions and mineralogy of the upper mantle. In: Schubert G (ed) Treatise on geophysics, vol 2, 2nd edn. Elsevier, Oxford, pp 7-31

Fumagalli P, Poli S, Fischer J, Merlini M, Gemmi M (2014) The highpressure stability of chlorite and other hydrates in subduction melanges: experiments in the system $\mathrm{Cr}_{2} \mathrm{O}_{3}-\mathrm{MgO}-\mathrm{Al}_{2} \mathrm{O}_{3}-\mathrm{SiO}_{2}-\mathrm{H}_{2} \mathrm{O}$. Contrib Mineral Petrol 167. doi:10.1007/s00410-014-0979-5

Garvie OG, Robinson DN (1984) The formation of kelyphite and associated sub-kelyphitic and sculptured surfaces on pyrope from kimberlite. In: Kornprobst J (ed) Kimberlites I: Kimberlites and related rocks. Developments in petrology 11A. Elsevier, New York, pp 359-370

Gasparik T (1984a) Experimental study of subsolidus phase relations and mixing properties of pyroxene in the system $\mathrm{CaO}-\mathrm{Al}_{2} \mathrm{O}_{3}-$ $\mathrm{SiO}_{2}$. Geochim Cosmochim Acta 48:2537-2545

Gasparik T (1984b) Two-pyroxene thermobarometry with new experimental data in the system $\mathrm{CaO}-\mathrm{MgO}-\mathrm{Al}_{2} \mathrm{O}_{3}-\mathrm{SiO}_{2}$. Contrib Mineral Petrol 87:87-97

Gasparik T, Newton RC (1984) The reversed alumina contents of orthopyroxene in equilibrium with spinel and forsterite in the system $\mathrm{MgO}-\mathrm{Al}_{2} \mathrm{O}_{3}-\mathrm{SiO}_{2}$. Contrib Mineral Petrol 85:186-196

Girnis AV, Brey GP (1999) Garnet-spinel-olivine-orthopyroxene equilibria in the $\mathrm{FeO}-\mathrm{MgO}-\mathrm{Al}_{2} \mathrm{O}_{3}-\mathrm{SiO}_{2}-\mathrm{Cr}_{2} \mathrm{O}_{3}$ system: II. Thermodynamic analysis. Eur J Mineral 11:619-636

Girnis AV, Brey GP, Doroshev AM, Turkin AI, Simon N (2003) The system $\mathrm{MgO}-\mathrm{Al}_{2} \mathrm{O}_{3}-\mathrm{SiO}_{2}-\mathrm{Cr}_{2} \mathrm{O}_{3}$ revisited: reanalysis of Doroshev et al'.s (1997) experiments and new experiments. Eur J Mineral 15:953-964

Godard G, Martin S (2000) Petrogenesis of kelyphites in garnet peridotites: a case study from the Ulten zone, Italian Alps. J Geodyn 30:117-145

Green DH, Falloon TJ (1998) Pyrolite: a ringwood concept and its current expression. In: Jackson INS (ed) The earth's mantle: composition, structure and evolution. Cambridge University Press, Cambridge, pp 311-380

Green DH, Liebermann RC (1976) Phase-equilibria and elastic properties of a pyrolite model for oceanic upper mantle. Tectonophysics 32:61-92

Green DH, Ringwood AE (1967) The stability fields of aluminous pyroxene peridotite and garnet peridotite and their relevance in upper mantle structure. Earth Planet Sci Lett 3:151-160

Green DH, Ringwood AE (1970) Mineralogy of peridotitic compositions under upper mantle conditions. Phys Earth Planet Interiors 3:359-371

Green DH, Hibberson WO, Kovacs I, Rosenthal A (2010) Water and its influence on the lithosphere-asthenosphere boundary. Nature 467:448-451

Green ECR, Holland TJB, Powell R, White RW (2012) Garnet and spinel lherzolite assemblages in $\mathrm{MgO}-\mathrm{Al}_{2} \mathrm{O}_{3}-\mathrm{SiO}_{2}$ and $\mathrm{CaO}-$ $\mathrm{MgO}-\mathrm{Al}_{2} \mathrm{O}_{3}-\mathrm{SiO}_{2}$ : thermodynamic models and an experimental conflict. J Metamorph Geol 30:561-577

Gudfinnsson GH, Presnall DC (1996) Melting relations of model lherzolite in the system $\mathrm{CaO}-\mathrm{MgO}-\mathrm{Al}_{2} \mathrm{O}_{3}-\mathrm{SiO}_{2}$ at $2.4-3.4 \mathrm{GPa}$ and the generation of komatiites. J Geophys Res Solid Earth 101:27701-27709

Hales AL (1969) A seismic discontinuity in lithosphere. Earth Planet Sci Lett 7:44-46

Hasterok D, Chapman DS (2011) Heat production and geotherms for the continental lithosphere. Earth Planet Sci Lett 307:59-70 
Holland TJB, Powell R (1998) An internally consistent thermodynamic data set for phases of petrological interest. J Metamorph Geol 16:309-343

Hunter RH, Taylor LA (1982) Instability of garnet from the mantle: glass as evidence of metasomatic melting. Geology 10:617-620

Jenkins DM, Newton RC (1979) Experimental determination of the spinel peridotite to garnet peridotite inversion at $900^{\circ} \mathrm{C}$ and $1000^{\circ} \mathrm{C}$ in the system $\mathrm{CaO}-\mathrm{MgO}-\mathrm{Al}_{2} \mathrm{O}_{3}-\mathrm{SiO}_{2}$, and at $900^{\circ} \mathrm{C}$ with natural garnet and olivine. Contrib Mineral Petrol 68:407-419

Jennings ES, Holland TJB (2015) A simple thermodynamic model for melting of peridotite in the system NCFMASOCr. J Petrol $56: 869-892$

Jones AG, Afonso JC, Fullea J, Salajegheh F (2014) The lithosphereasthenosphere system beneath Ireland from integrated geophysical-petrological modeling-I: observations, 1D and 2D hypothesis testing and modeling. Lithos 189:28-48

Kaus BJP, Connolly JA, Podladchikov YY, Schmalholz SM (2005) Effect of mineral phase transitions on sedimentary basin subsidence and uplift. Earth Planet Sci Lett 233:213-228

Klemme S (2004) The influence of $\mathrm{Cr}$ on the garnet-spinel transition in the earth's mantle: experiments in the system $\mathrm{MgO}-\mathrm{Cr}_{2} \mathrm{O}_{3}-$ $\mathrm{SiO}_{2}$ and thermodynamic modelling. Lithos 77:639-646

Klemme S, O'Neill HS (2000a) The effect of Cr on the solubility of $\mathrm{Al}$ in orthopyroxene: experiments and thermodynamic modelling. Contrib Mineral Petrol 140:84-98

Klemme S, O'Neill HS (2000b) The near-solidus transition from garnet Iherzolite to spinel Iherzolite. Contrib Mineral Petrol 138:237-248

Klemme S, Ivanic TJ, Connolly JAD, Harte B (2009) Thermodynamic modelling of Cr-bearing garnets with implications for diamond inclusions and peridotite xenoliths. Lithos 112:986-991

Kushiro I, Syono Y, Akimoto S (1967) Effect of pressure on garnetpyroxene equilibrium in the system $\mathrm{MgSiO}_{3}-\mathrm{CaSiO}_{3}-\mathrm{Al}_{2} \mathrm{O}_{3}$. Earth Planet Sci Lett 2:460-464

Lee CTA (2003) Compositional variation of density and seismic velocities in natural peridotites at STP conditions: implications for seismic imaging of compositional heterogeneities in the upper mantle. J Geophys Res. doi:10.1029/2003JB002413

MacGregor ID (1974) The system $\mathrm{MgO}-\mathrm{Al}_{2} \mathrm{O}_{3}-\mathrm{SiO}_{2}$ : solubility of $\mathrm{Al}_{2} \mathrm{O}_{3}$ in enstatite for spinel and garnet peridotite compositions. Am Mineral 59:110-119

Menzies MA, Hawkesworth CJ (1987) Mantle metasomatism. Academic Press, London

Milholland CS, Presnall DC (1998) Liquidus phase relations in the $\mathrm{CaO}-\mathrm{MgO}-\mathrm{Al}_{2} \mathrm{O}_{3}-\mathrm{SiO}_{2}$ system at $3.0 \mathrm{GPa}$ : the aluminous pyroxene thermal divide and high-pressure fractionation of picritic and komatiitic magmas. J Petrol 39:3-27

Mukhopadhyay B (1991) Garnet breakdown in some deep seated garnetiferous xenoliths from the central Sierra Nevada: petrologic and tectonic implications. Lithos 27:59-78

Nickel KG (1986) Phase equilibria in the system $\mathrm{SiO}_{2}-\mathrm{MgO}-\mathrm{Al}_{2} \mathrm{O}_{3}-$ $\mathrm{CaO}-\mathrm{Cr}_{2} \mathrm{O}_{3}$ (SMACCR) and their bearing on spinel/garnet lherzolite relationships. Neues Jahrbuch Fur Mineralogie-Abhandlungen 155:259-287

Nickel KG (1989) Garnet-pyroxene equilibria in the system SMACCR $\left(\mathrm{SiO}_{2}-\mathrm{MgO}-\mathrm{Al}_{2} \mathrm{O}_{3}-\mathrm{CaO}-\mathrm{Cr}_{2} \mathrm{O}_{3}\right)$ : the Cr-geobarometer. In: Ross J, Jaques AL, Ferguson J, Green DH, O'Reilly SY, Danchin RV, Janse AJA (eds) Kimberlites and related rocks, vol. 2, their mantle/crust setting, diamonds and diamond exploration. Geological Society of Australia Special Publication, vol 14. Blackwell Scientific, Victoria, pp 901-912

Nimis P, Grütter H (2010) Internally consistent geothermometers for garnet peridotites and pyroxenites. Contrib Mineral Petrol 159:411-427

Obata M (1976) Solubility of $\mathrm{Al}_{2} \mathrm{O}_{3}$ in orthopyroxenes in spinel and plagioclase peridotites and pisnel pyroxenite. Am Mineral 61:804-816
Obata M (2011) Kelyphite and symplectite: textural and mineralogical diversities and universality, and a new dynamic view of their structural formation. In: Sharkov V (ed) New frontiers in tectonic research—general problems, sedimentary basins and island arcs. InTech, pp 93-122

O'Hara MJ, Richards SW, Wilson G (1971) Garnet-peridotite stability and occurrence in crust and mantle. Contrib Mineral Petrol $32: 48-68$

O'Neill HS (1981) The transition between spinel lherzolite and garnet lherzolite, and its use as a geobarometer. Contrib Mineral Petrol 77:185-194

Pankhurst RJ, Rapela CW, Fanning CM, Márquez M (2006) Gondwanide continental collision and the origin of Patagonia. Earth Sci Rev 76:235-257

Pearson DG, Wittig N (2008) Formation of Archaean continental lithosphere and its diamonds: the root of the problem. J Geol Soc 165:895-914

Perkins D, Newton RC (1980) The compositions of coexisting pyroxenes and garnet in the system $\mathrm{CaO}-\mathrm{MgO}-\mathrm{Al}_{2} \mathrm{O}_{3}-\mathrm{SiO}_{2}$ at $900^{\circ}-1100^{\circ} \mathrm{C}$ and high pressures. Contrib Mineral Petrol 75:291-300

Podladchikov YY, Poliakov ANB, Yuen DA (1994) The effect of lithospheric phase transitions on subsidence of extending continental lithosphere. Earth Planet Sci Lett 124:95-103

Reid AM, Dawson JB (1972) Olivine-garnet reaction in peridotites from Tanzania. Lithos 5:115-124

Revenaugh J, Jordan TH (1991) Mantle layering from scs reverberations. 3. The upper mantle. J Geophys Res Solid Earth 96:19781-19810

Ringwood AE (1975) Composition and petrology of the Earth's mantle. McGraw-Hill, London

Sakamaki T, Suzuki A, Ohtani E, Terasaki H, Urakawa S, Katayama Y, Funakoshi KI, Wang Y, Hernlund JW, Ballmer MD (2013) Ponded melt at the boundary between the lithosphere and asthenosphere. Nat Geosci 6:1041-1044

Sen $\mathrm{G}$ (1985) Experimental determination of pyroxene composition in the system $\mathrm{CaO}-\mathrm{MgO}-\mathrm{Al}_{2} \mathrm{O}_{3}-\mathrm{SiO}_{2}$ at $900-1200^{\circ} \mathrm{C}$ and $10-15$ kbar using $\mathrm{PbO}$ and $\mathrm{H}_{2} \mathrm{O}$ fluxes. Am Min 70:678-695

Simon NSC, Podladchikov YY (2008) The effect of mantle composition on density in the extending lithosphere. Earth Planet Sci Lett 272:148-157

Skewes MA, Stern CR (1979) Petrology and geochemistry of alkali basalts and ultramafic inclusions from the Palei-Aike volcanic field in southern Chile and the origin of the Patagonian plateau lavas. J Volcanol Geotherm Res 6:3-25

Špaček P, Ackerman L, Habler G, Abart R, Ulrych J (2013) Garnet breakdown, symplectite formation and melting in basanitehosted peridotite xenoliths from Zinst (Bavaria, Bohemian Massif). J Petrol 54:1691-1723

Stern CR, Kilian R, Olker B, Hauri EH, Kyser TK (1999) Evidence from mantle xenoliths for relatively thin $(<100 \mathrm{~km})$ continental lithosphere below the Phanerozoic crust of southernmost South America. Lithos 48:217-235

Stern TA, Henrys SA, Okaya D, Louie JN, Savage MK, Lamb S, Sato $\mathrm{H}$, Sutherland R, Iwasaki T (2015) A seismic reflection image for the base of a tectonic plate. Nature 518:85-88

Stixrude L, Lithgow-Bertelloni C (2005) Mineralogy and elasticity of the oceanic upper mantle: origin of the low-velocity zone. J Geophys Res Solid Earth 110. doi:10.1029/2004JB002965

Suzuki A, Othani E (2003) Density of peridotite melts at high pressure. Phys Chem Minerals 30:449-456

Van Achterbergh E, Griffin WL, Stiefenhofer J (2001) Metasomatism in mantle xenoliths from the Letlhakane kimberlites: estimation of element fluxes. Contrib Mineral Petrol 141:397-414

Walter MJ (1998) Melting of garnet peridotite and the origin of komatiite and depleted lithosphere. J Petrol 39:29-60 
Walter MJ, Presnall DC (1994) Melting behaviour of simplified lherzolite in the system $\mathrm{CaO}-\mathrm{MgO}-\mathrm{Al}_{2} \mathrm{O}_{3}-\mathrm{SiO}_{2}-\mathrm{Na}_{2} \mathrm{O}$ from 7 to 35 kbar. J Petrol 35:329-359

Walter MJ, Katsura T, Kubo A, Shinmei T, Nishikawa O, Ito E, Lesher C, Funakoshi K (2002) Spinel-garnet lherzolite transition in the system $\mathrm{CaO}-\mathrm{MgO}-\mathrm{Al}_{2} \mathrm{O}_{3}-\mathrm{SiO}_{2}$ revisited: an in situ X-ray study. Geochim Cosmochim Acta 66:2109-2121

Wang J, Hattori KH, Li JP, Stern CR (2008) Oxidation state of Paleozoic subcontinental lithospheric mantle below the Pali Aike volcanic field in southernmost Patagonia. Lithos 105:98-110
Webb SAC, Wood BJ (1986) Spinel-pyroxene-garnet relationships and their dependence on $\mathrm{Cr} / \mathrm{Al}$ ratio. Contrib Mineral Petrol 92:471-480

Wood BJ, Yuen DA (1983) The role of lithospheric phase transitions on seafloor flattening at old ages. Earth Planet Sci Lett 66:303-314

Ziberna L, Klemme S, Nimis P (2013) Garnet and spinel in fertile and depleted mantle: insights from thermodynamic modelling. Contrib Mineral Petrology 166:411-421 